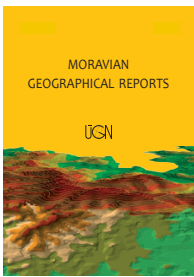

MORAVIAN GEOGRAPHICAL REPORTS

\title{
Air charter leisure traffic and organised tourism in Poland: Are charters passé?
}

\author{
Zbigniew TAYLOR ${ }^{\text {* }}$
}

\begin{abstract}
Data from a number of tourism and transport sources are used in this analysis, concentrating on Poland: the largest tour operators and areas in which air carriers are likely to have the greatest impact. The top 25 air charter carriers identified are examined closely in terms of connections, and the geographical characteristics of these links are highlighted. The research reveals substantial differences in models of air leisure traffic between Western Europe and Poland. These are of a quantitative, but also a qualitative nature, and reflect the disparate levels of affluence of societies, different mobility patterns, and various experiences, adventures and demands on the part of travellers. Overall, charter traffic in Poland is still seen to be flourishing, while that in Western Europe is in relative decline.
\end{abstract}

Key words: transport for tourism, passenger traffic, air charters, tour operators, package holidays, tourism exporting economy, Poland

Article history: Received 6 November 2015; Accepted 10 May 2016; Published 31 December 2016

\section{Introduction}

In Poland, it is possible to observe a dramatic development of tourist traffic (and a breakthrough in mobility overall) since the fall of communism at the turn of the 1990s - with the travel involved being both domestic and international. This development would not have been possible without a parallel increase in the carriage capacity characterising the transport companies that serve the tour operators active in the market. An absolute majority of cases of tourism organised by Polish tour operators involves the use of aircraft (these taking $45.7 \%$ of tourists and accounting for $47.7 \%$ of the turnover) as the primary means, along with possibly one or more other means (with $44.3 \%$ of tourists and $48.8 \%$ of the turnover ${ }^{1}$ ).

According to several authors (e.g. Doganis, 2006, 2010; Graham et al., 2008; Buck and Ley, 2004), charter airlines are seen as a declining sector in the short- and medium-haul markets because they cannot survive competition from the low-cost carriers (LCCs). Such statements, however, typically come from Western contributors, who neglect specific trends in emerging markets like the Central Eastern European countries. As a result, the work detailed in this paper aims to fill this gap, considering Poland as a case study.

In the mass tourist traffic organised by the largest tour operators, the flights occurring mainly take the form of charters. Tour operators located in Poland above all organise standard tours to popular localities on terms of special interest, incentive tours (travel), or (mostly) inclusive tours flight packages organised with the use of a special discount fare available for this type of travel only ${ }^{2}$. It can therefore be said, with some simplification, that charter flights almost exclusively serve organised mass foreign outward tourism, while - on the other hand - not all tourist flights take the form of charters. It is in fact estimated that about $90 \%$ of all tour-operators' customers use charter flights (leaving aside customers' own access, e.g. by car or aeroplane).

The purpose of this paper is to provide an in-depth insight into Poland's air charter traffic and its nature when compared with the matured markets of Western Europe. To that end, the remainder of this paper is organised as follows.

\footnotetext{
${ }^{a}$ Stanisław Leszczycki Institute of Geography and Spatial Organisation, Polish Academy of Sciences, Warsaw, Poland (*corresponding author: Z. Taylor, e-mail: z.taylor@twarda.pan.pl)
}

\footnotetext{
${ }^{1}$ Author's calculations, based on various sources (cf. Section 3 of this paper). This refers to all data, unless otherwise stated.

2 The growth of inclusive tour charters contributed significantly to the development of tourism in Spain from the 1960s onwards, and in other Mediterranean countries during the 1970s and early 1980s. Besides the most common inclusive tour charters, the literature also mentions one-stop inclusive tour charters, charters for special events, and common purpose charters (including charters for one's own use and charters for affinity groups) (Gardzińska and Meyer, 2008).
} 
Section 2 reviews the literature, while Section 3 describes the data used and provides details on the methodology. The main part of the paper is then Section 4, which presents an analysis of the largest air charter carriers and the principal destinations of charter flights from/to Poland, respectively. Finally, some discussion is engaged in Section 5 and conclusions arrived at in Section 6.

\section{Theoretical framework}

Tourism is inevitably connected with the movement of human beings in space. The meeting of needs in this regard implies a change of place of stay, and therefore the generation of demand for transport. It is estimated that tourism in Europe is responsible for 15 to $20 \%$ of passenger$\mathrm{km}$ accounted for by surface transport, and in air transport this share is much greater (Peteers et al., 2007). This is also the case for Poland, where significant growth in tourist traffic, domestic as well as international, has been observed since 1990.

"Transport provision is a permissive factor in much tourist/recreation development, itself a product of increasing mobility, leisure time and affluence" (Halsall, 1992, p. 175). In relation to the supply side of tourism transport, Hall (2008, p.199) distinguishes four general functions: “(1) linking the source market with the host destination; (2) providing mobility and access within a destination area/ region/country; (3) providing mobility and access within an actual tourism attraction; and (4) facilitating travel along a recreational route, where both the transport form and nature of the route may combine or act singly to provide the tourism experience." In this paper, the focus will be on the first of these functions of transport.

Wheatcroft (1998) analyses the global relationship between the airline industry and tourism, seeing this as a mixture of technological factors, market pressures and regulatory policies. Bieger and Wittmer (2006) in turn approach tourism as a stimulator in air transport, while Graham et al. (2008) discuss the implications of the aviation industry for leisure travel on a worldwide scale. Hall (1999) explores two sets of conceptual issues at the interface between transport and tourism:

1. transport as a culture gatekeeper to host-tourist interaction; and

2. the role of tourist mobility at the local level and its impact on inequality and externality effects. The first issue is in fact a borrowing of Ioannides's concept of tour operators as gatekeepers of tourism (Ioannides, 1998).

In the context of this paper, many studies have analysed transport, especially aviation, albeit without any special reference to tourism. Prideaux (2000) identifies the significance of the transport system in destination development, concluding that those without airport facilities are largely restricted to markets accessible by car, while air travel is a key element in the winning of new markets beyond the reasonable reach thereof.

Issues relating to the low-cost airlines have dominated the literature recently, however, since "LCC growth has been at the expense of the full service/legacy carriers and, even more so, of the charter airlines" (Graham, 2008, p. 232). Low-cost carriers (LCCs) are a reflection of the liberalisation of air transport. Since the liberalisation of the intra-European market, airline competition has increased in most parts of Europe, especially due to the penetration of LCCs into a wider array of airports. "Taking advantage of the new freedom of access to the market, various airlines structured themselves to the low-cost model, which consists of making maximum use of their aircraft and of the work force, reducing the costs related to comfort and making use where possible of various incentives offered by governments (...). Reducing costs allows them to offer low fares" (Dobruszkes, 2009b, p. 423). Low wages, low incomes and the weakness of the flag carriers are among the elements favouring the development of LCCs in CEE countries (Dobruszkes, 2006).

As Dobruszkes and Mondou (2013, p. 30) write: "LCCs tend to cannibalize the charter business on short- and medium-haul markets". Francis et al. (2006) examine and characterise the factors which have encouraged or inhibited the spatial and temporal spread of LCCs in different countries of the world. The dynamic expansion of European LCCs is discussed as a contradiction inherent in the relationships between air transport and sustainability by Graham and Shaw (2008). Dobruszkes (2009b, 2013, 2014) analyses how European low-cost carriers have adapted and developed their networks to the CEE countries as a result of the liberalisation of air space parallel to EU enlargement in 2004.

The world's charter services are gradually being replaced by scheduled operations as a result of air transport deregulation/liberalisation. ${ }^{3}$ The situation in Europe is similar "but the sheer scale of the continent's charter market has meant that this remains large. Much of the European charter market involves short to medium distance journeys, with the average sector flown by the larger charter carriers being typically around 2,500 km" (Williams, 2008, p.85). In the case of some major leisure routes to the Mediterranean, over 90 per cent of passengers travel on charter flights (Doganis, 2006, p. 184). As Williams further writes, "the charter airlines owned by [European] tour operators accounted for 42 per cent of (...) aircraft" in 2007 (Williams, 2008, p. 90), though in the case of Poland this share has been much smaller. More information on the air transport market in CEE countries, including Poland, can be found in a recently published paper by Jankiewicz and Huderek-Glapska (2016).

For the purpose of this paper, a matter of crucial importance is an understanding of the aviation market in terms of the comparison of costs borne by various types of air operators. Barrett estimated a charter product's costs "to range between 32 per cent and 37 per cent of the costs of the traditional scheduled airline product" (Barrett, 2008, p. 104). Doganis - in a cascade analysis of the LondonAthens route - estimated even larger savings of 69 per cent, for a charter operation over a full-service scheduled carrier, and of 10 per cent when the comparison is with LCCs (Doganis, 2006). A given charter airline's costs per passenger amount to only 46 per cent of scheduled costs (Doganis, 2010). The major cost advantages of charters lie in their usage of larger and more economical aircraft, fuller

\footnotetext{
3 "In spite of the existence of a few differences (e.g. deregulation may take place within a country whereas liberalisation across countries), these last two terms are often used interchangeably" (Graham et al., 2008, p. 370). Some treat liberalisation, however, as "a misnomer for re-regulation, the replacement of one set of interventionist rules by another more flexible set" (Graham, 1998, p.88).
} 
daily utilisation of aircraft (flights also through the night), close matching between capacity offered and demand, higher passenger load factors and very low sales or advertising costs (Doganis, 2006). "It is apparent that the combination of larger aircraft, longer flight sectors, greater aircraft and crew utilisation, high seating configurations and higher load factors provides the typical charter airline with significantly lower costs per passenger carried than scheduled airlines" (Williams, 2008, p. 96). Moreover, distribution costs are virtually non-existent for the charter airlines, since these are taken on by the tour operators. As Buck and Lei (2004, p. 74) write, "from the start, cost reduction has been the primary aim of charter operations". Therefore, the savings of charters are also greater than those achieved by LCCs.

\section{Sources, methods of data collection and processing}

Despite the existence of at least several institutions involved in the collection of data on companies, there is no single proper and reliable base on tour operators and carriers - a circumstance that has necessitated the creation of dedicated databases.

The basic sources in the creation of a homogeneous base of tour operators have been single items of information on enterprises included in Hoppenstedt Bonnier Information Polska (HBI). On the basis of these, a list of 398 enterprises with main and additional ${ }^{4}$ activities characterised by code 6,330 of the European Classification of Activities (Activity of tourist agencies, pilots and tour guides; remaining tourist activity) - and with an annual turnover above one million zloties ${ }^{5}$ - has been drawn up. This list was then perforce reduced as a consequence of the bankruptcy or closure of 20 tour operators in the years 2010-2012, as checked in the Central Register of Tourist Agencies and Tourist Brokers (Centralna Ewidencja Organizatorów Turystyki i Pośredników Turystycznych, abbreviated to CEOTiPT), and compared with reports in the periodical Wiadomości Turystyczne (Wiadomości Turystyczne, 2012; 2013).

The final list consists of the largest tour operators (38 entities, i.e. $1.2 \%$ of their total number) with annual turnover from the organisation of tourism exceeding 10 million zloties (as of 2012). The list has been updated and supplemented with certain missing information, on the basis of the aforementioned Touroperatorzy reports, as well as data and information from the National Registry (Krajowy Rejestr Sądowy, KRS). The latter is made available by the firm InfoVeriti (2013). Annual reports of larger companies and official websites of entities have also been taken into account. All calculations and generalisations in this paper concern data on the top 38 tour operators, from which further conclusions have been drawn.

The second database comprises charter carriers. The basis for this has been provided by the list of the 25 most important air charter carriers running flights from/ to Poland, as published by the country's Civil Aviation Authority (Urząd Lotnictwa Cywilnego, ULC). Catalogues and websites of tour operators cooperating with selected carriers have been used for supplementary information.
In the case of a lack of official data, connections between the tour operator researched and carriers have been looked for using key words (a combination of the tour operator's name with the means of transport, or names of carriers) in Polish and English languages. In this case, commonlyused Internet browsers have been used. Information on air carriers has been supplemented using data from InfoVeriti (where registration is in Poland) and from press materials, websites and the annual reports of entities (where registration is in Poland and abroad). The database, despite featuring a relatively small number of air carriers (just 25), encompasses an absolute majority of the passengers served at Polish airports. Other carriers, despite their presence in large numbers, actually participate in carriage at minimum levels only. Therefore, given that Dobruszkes and Mondou (2013, p. 33) write that "there are few available data sources for charter airlines services", the author of this paper is in a relatively fortunate situation, especially given the fact that some additional information on the geographical distribution of flights is available (cf. Section 4).

\section{Results}

\subsection{Air charter carriers in the service of Polish tour operators}

While scheduled air traffic takes part to only some unidentified extent in the servicing of the Polish tourist market, charter traffic serves foreign tourist flights almost exclusively. The difference between the number of all passengers on charter flights $\left(3,295,488^{6}\right)$ and charter flights in international traffic is 128,515 people only (these calculations are based on data for Polish airports, collected by the country's Civil Aviation Authority (ULC)). This difference reflects commissioned flights, flights for firms, as well as the necessity for the supply/retrieval of certain participants on excursions to/from hubs prior to departures abroad.

"Charter airlines predominantly serve leisure routes on a weekly basis, carrying clients for tour operators" (Buck and Lei, 2004, p. 72). The charter market is extremely seasonal, achieving a maximum during the summer holidays (JulySeptember) and a minimum in winter (December-February). The charter market is also very much differentiated, and characterised by variations in operations and ownership. The absolute majority of charter carriers is in private hands.

According to the ULC data, a dominant share among charter lines in the Polish market is taken by 25 carriers (multiple flights entailing the regular systematic transfer of customers), with these together servicing some $96.8 \%$ of all passengers. The remaining $3.2 \%$ of passengers are served by as many as 101 charter carriers, sometimes very exotic. It may be supposed that the cooperation between tour operators and the latter firms is of a more incidental nature (one can call them ad hoc charters), not being based around permanent agreements at least. Table 1 gives a concise characterisation of carriers, and of the tour operators cooperating with them. Unlike the case of scheduled air traffic, in an absolute majority of cases it has been possible to determine which tour operators collaborate with which charter carriers.

\footnotetext{
${ }^{4}$ Some entities, while actually active in organising tourist events, may nevertheless be registered under a completely different category of activity.

${ }^{5} € 1 \approx 4.0-4.3$ zloties (2012).

${ }^{6}$ For comparison: there were 9,915,229 passengers in LCC traffic, and 10,863,918 in scheduled traffic excluding LCCs (2012).
} 


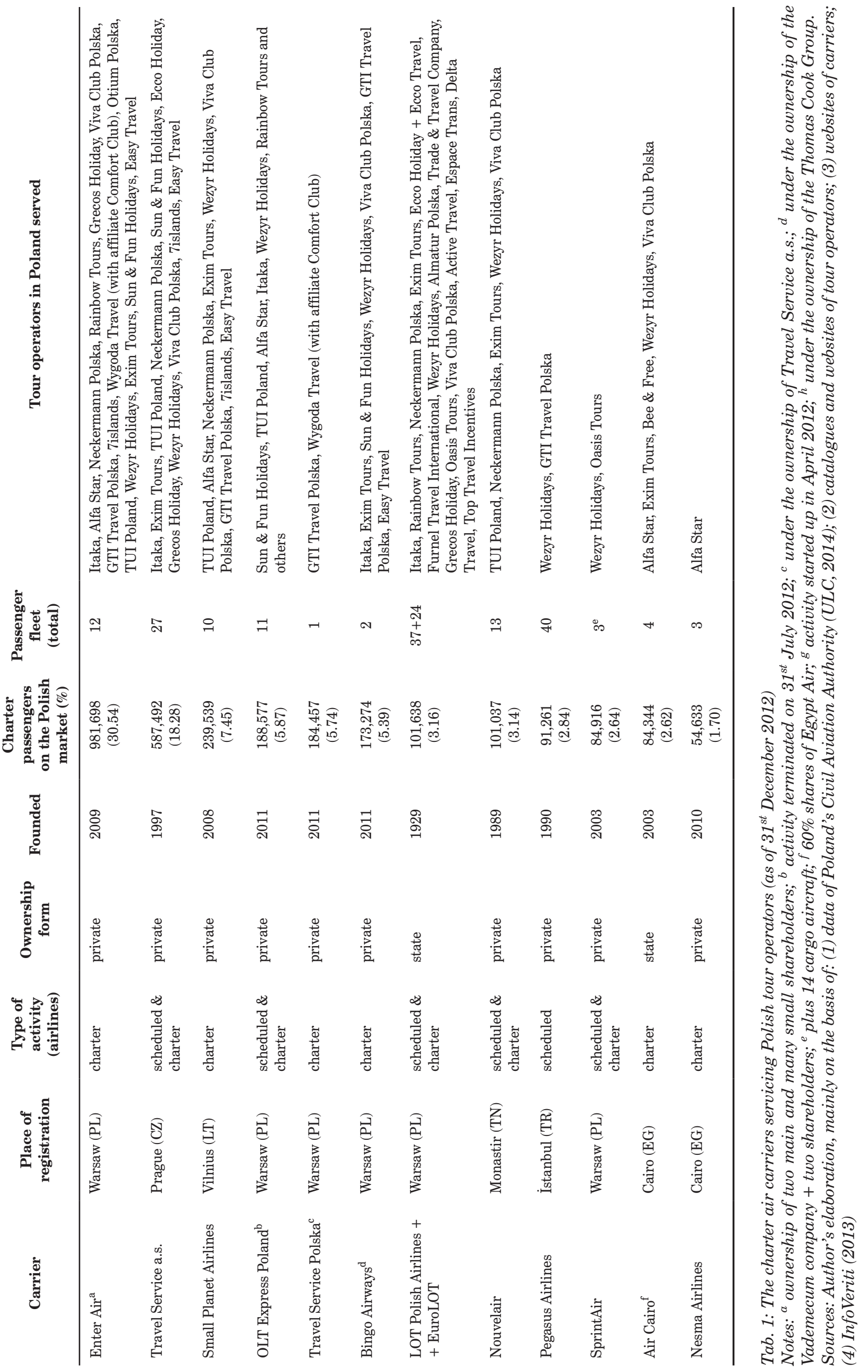




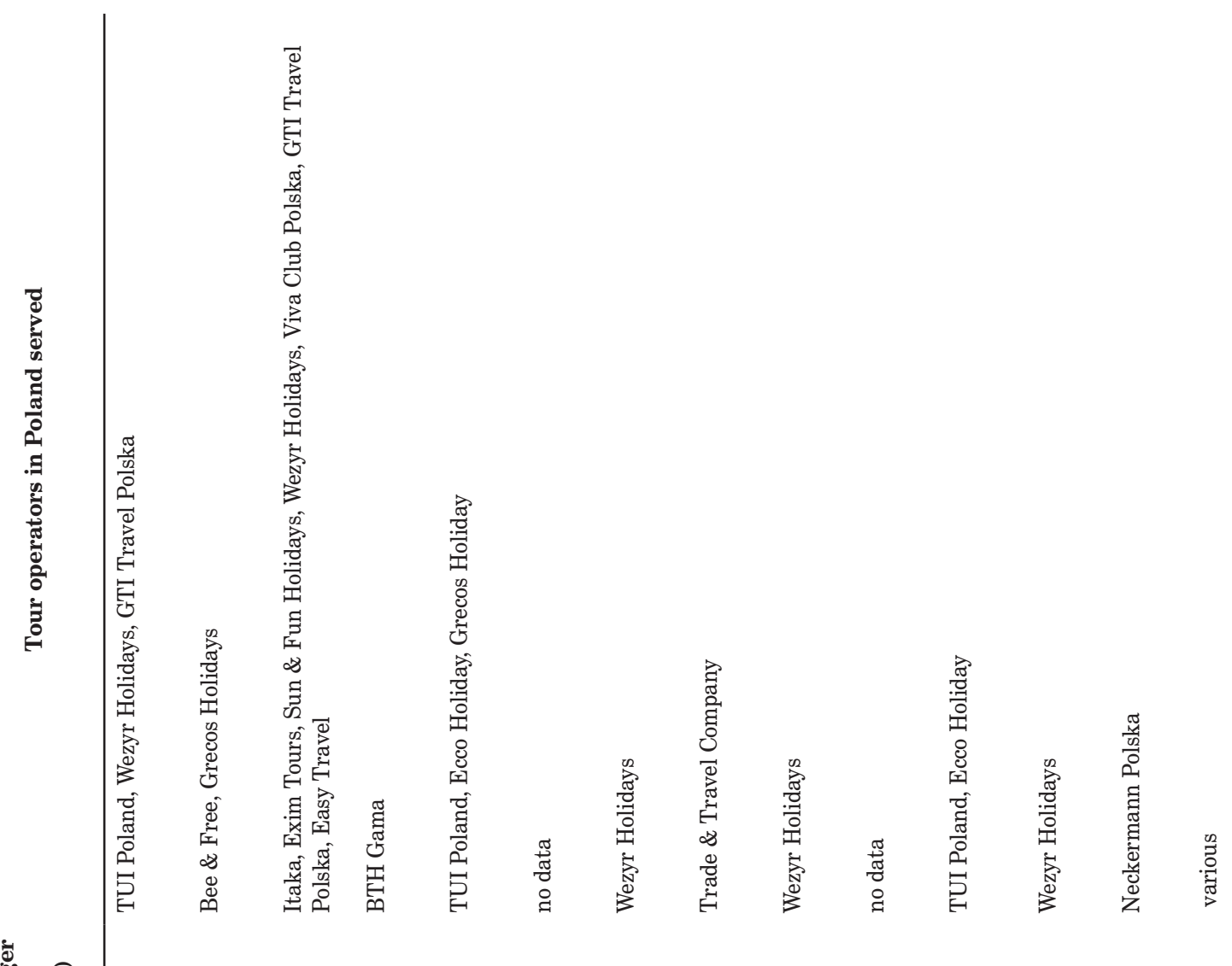

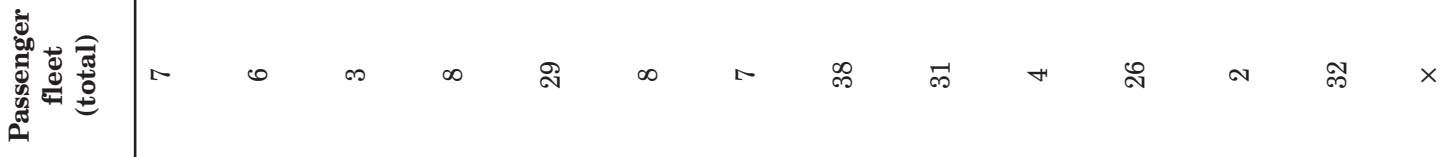

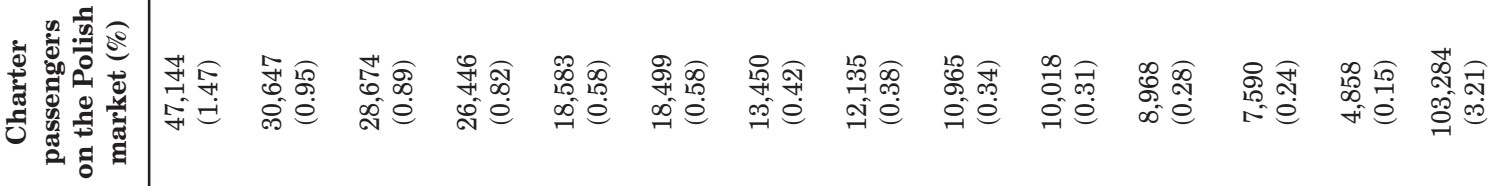

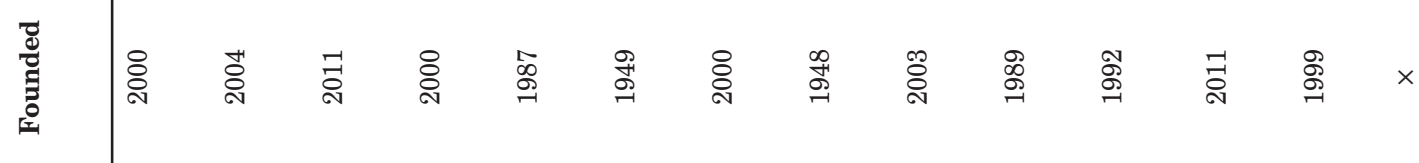

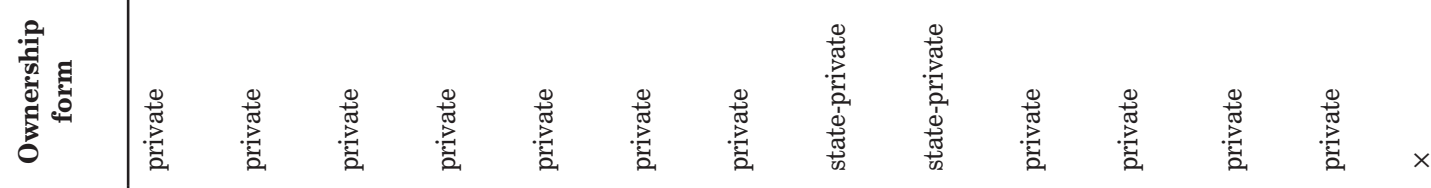

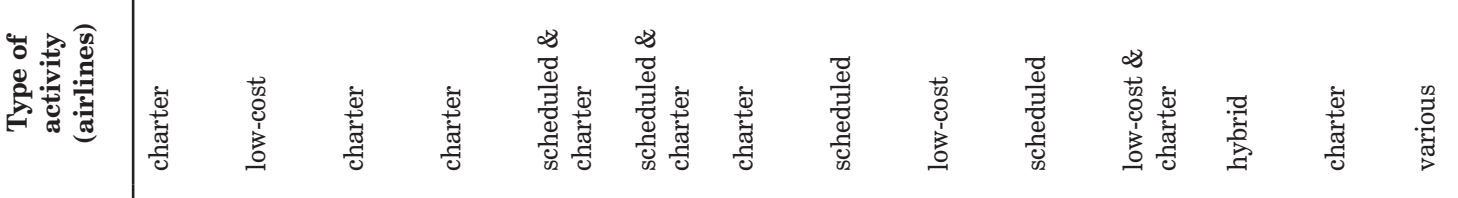

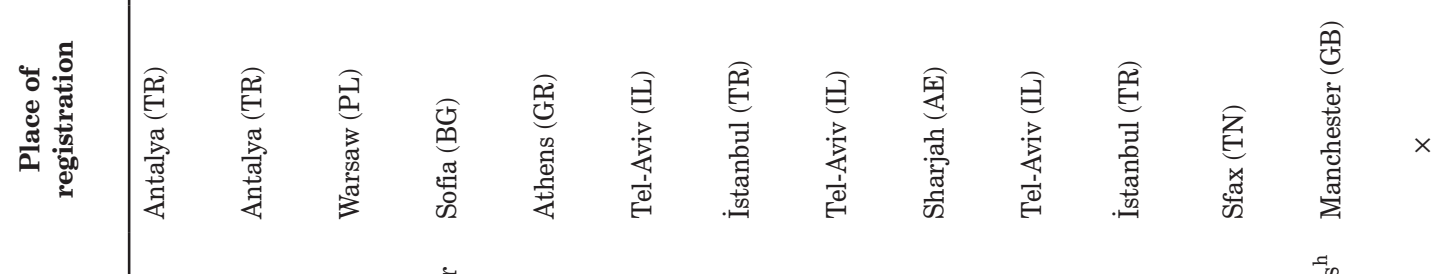

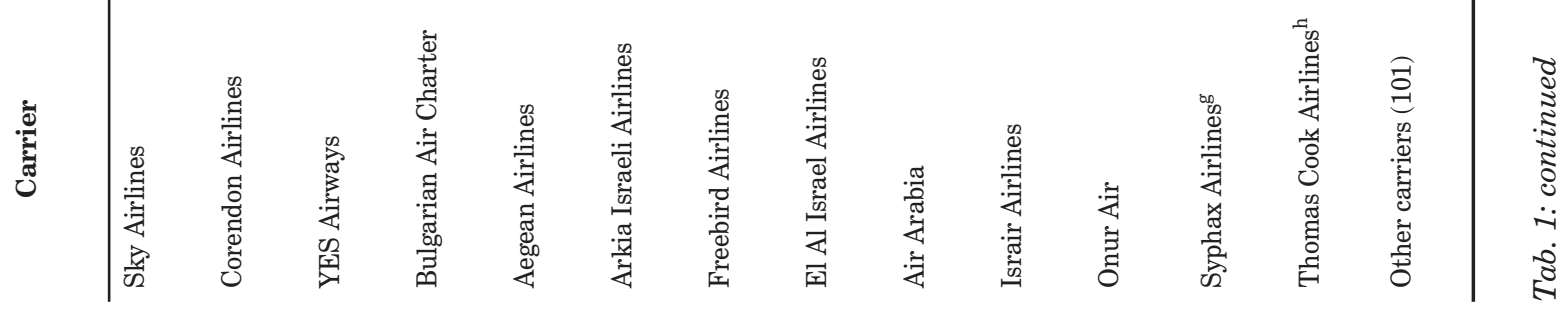


The largest share among the charter carriers is that taken by the private Polish Enter Air, which serves more than $30.5 \%$ of all passengers and cooperates with at least 16 large tour operators. What is of interest here is that a turnover of some 750 million zloties is achieved on the basis of a fleet consisting of just 12 aircraft. Besides the Polish market, the line is also present in France (with a base at Paris-Charles de Gaulle Airport), in the Czech Republic (Prague Ruzyně Airport), and to some extent also in Italy and Spain. Annually, Enter Air carries about 1.5 million passengers, including 981,698 on connections to/from Poland. The aircraft are therefore in the air for a much longer time than their scheduled counterparts - as was noted by Williams (2001).

A large (18.3\%) share in the servicing of the Polish charter market has been taken by the Czech-based private carrier Travel Service, as well as its affiliate Travel Service Polska (5.7\%). The two carriers cooperate with a dozen or so tour operators but - interestingly - each deals with a different set. The Lithuanian private charter carrier Small Planet Airlines also takes a substantial share (7.5\%) in the servicing of passengers in Poland. Active for several months only,

\begin{tabular}{|c|c|c|}
\hline \multirow{2}{*}{ Destination } & \multicolumn{2}{|c|}{ Passengers } \\
\hline & Number & Percentage \\
\hline Hurghada & 416,575 & 13.15 \\
\hline Antalya & 399,637 & 12.62 \\
\hline Sharm el-Sheikh & 268,590 & 8.48 \\
\hline Enfidha & 143,956 & 4.55 \\
\hline Heraklion (Iraklion, Crete) & 128,210 & 4.05 \\
\hline Fuerteventura & 120,657 & 3.81 \\
\hline Tel-Aviv & 110,722 & 3.50 \\
\hline Burgas & 102,114 & 3.22 \\
\hline Rhodes & 98,489 & 3.11 \\
\hline Tenerife & 98,274 & 3.10 \\
\hline Bodrum & 87,285 & 2.76 \\
\hline Marsa Alam & 72,540 & 2.29 \\
\hline Palma de Mallorca & 68,806 & 2.17 \\
\hline Kos & 60,856 & 1.92 \\
\hline Chania (Khania, Crete) & 55,643 & 1.76 \\
\hline Monastir & 53,217 & 1.68 \\
\hline Varna & 52,754 & 1.67 \\
\hline Dalaman & 51,013 & 1.61 \\
\hline Kerkyra & 49,996 & 1.58 \\
\hline Izmir & 47,806 & 1.51 \\
\hline Zakynthos & 45,555 & 1.44 \\
\hline Las Palmas & 44,939 & 1.42 \\
\hline Agadir & 39,216 & 1.24 \\
\hline Lanzarote & 38,224 & 1.21 \\
\hline Barcelona & 36,398 & 1.15 \\
\hline Other airports & 475,500 & 15.01 \\
\hline Total (international traffic) & $3,166,972$ & 100.00 \\
\hline
\end{tabular}

Tab. 2: Passengers served at Polish airports on international charter flights, categorised by destination (in 2012). Source: Civil Aviation Authority (ULC, 2014)
OLT Express Poland carried 5.9\% of all passengers in 2012, while the other private Polish airline - Bingo Airways took 5.4\%. Alongside scheduled services, charter flights are also provided by the state-owned LOT Polish Airlines, jointly with its affiliate EuroLOT (with the two combined taking a $3.2 \%$ share). The list of the largest charter operators, transporting over 100,000 people, is completed by the Tunisian Nouvelair $(3.1 \%)$. The remaining smaller charter carriers are mainly from reception countries, such as Egypt, Turkey, Greece, Bulgaria, Israel and the United Arab Emirates.

As may already be seen, it is charter carrier airlines from Central and Eastern Europe that prevail here, Polish companies most of all. The Polish carriers' share is $61.8 \%$ of passengers, and this is of course a much higher figure than in the case of the scheduled flights $(34.6 \%)$. This is mainly the result of the activities of Enter Air, OLT Express Poland, Travel Service Polska, Bingo Airways, LOT Polish Airlines + EuroLOT, SprintAir, and YES Airways.

A specific feature of the Polish market is also seen in the fact that a majority of passengers (78.5\%) are served by domestic charter carriers, and not in their role as providers of scheduled services, but performing charter operations only. All those using Lithuanian and Egyptian carriers are also customers of charter operators, though the opposite situation applies in the case of the Czech and Tunisian carriers, wherein only scheduled operators offer charter flights.

Just as charter carriers are first and foremost private companies, so the majority of customers are also passengers of private operators. Exceptions are Egypt, Israel and Poland, in which private airlines transport 39.3, 70.2 and $94.2 \%$ of passengers, respectively.

\subsection{The main destinations of charter flights from Poland in $\mathbf{2 0 1 2}$}

Data provided on a webpage of the Civil Aviation Authority (2014), used in conjunction with a report entitled Loty czarterowe z Polski - lato 2012, drawn up by the tanieloty.pl Booking Centre (Tanie loty, 2012), allow considerable familiarity with the main directions of charter flights from/to Poland to be gained, and in relation to several aspects.

Where do Polish tourists using international charter connections within mass organised tourist traffic fly to? Like travellers from other parts of Europe, they mainly take charter flights from Poland in a southerly direction, to the Mediterranean, Red Sea, Black Sea and Canary Islands. The spatial distribution of the most attractive destinations, however, is far from regular - with the visible majority of localities in the eastern part of the basin. Thus, the largest flows of tourists lead to the Egyptian Hurghada and Sharm el-Sheikh, as well as Turkish Antalya (Tab. 2, Fig. 1). Such a concentration of passenger charter flights probably reflects the choice of destinations located by warm seas, but also offering competitive prices.

The remaining (several percent) shares of passengers on charter flights from Poland have other centres located within the same geographical area (Tab. 2). In the eastern part of the Mediterranean, one can distinguish Heraklion (Iraklion) on Crete, Tel-Aviv, Greek Rhodes and Kos, and Turkish Bodrum. In the western part of the Black Sea the main destinations are Bulgarian Burgas and Varna, and on the coast of the Red Sea (apart from Hurghada and Sharm el-Sheikh), the relatively new leisure centre of Marsa Alam. On the southern coast of the Mediterranean it is Enfidha and Monastir in Tunisia that 


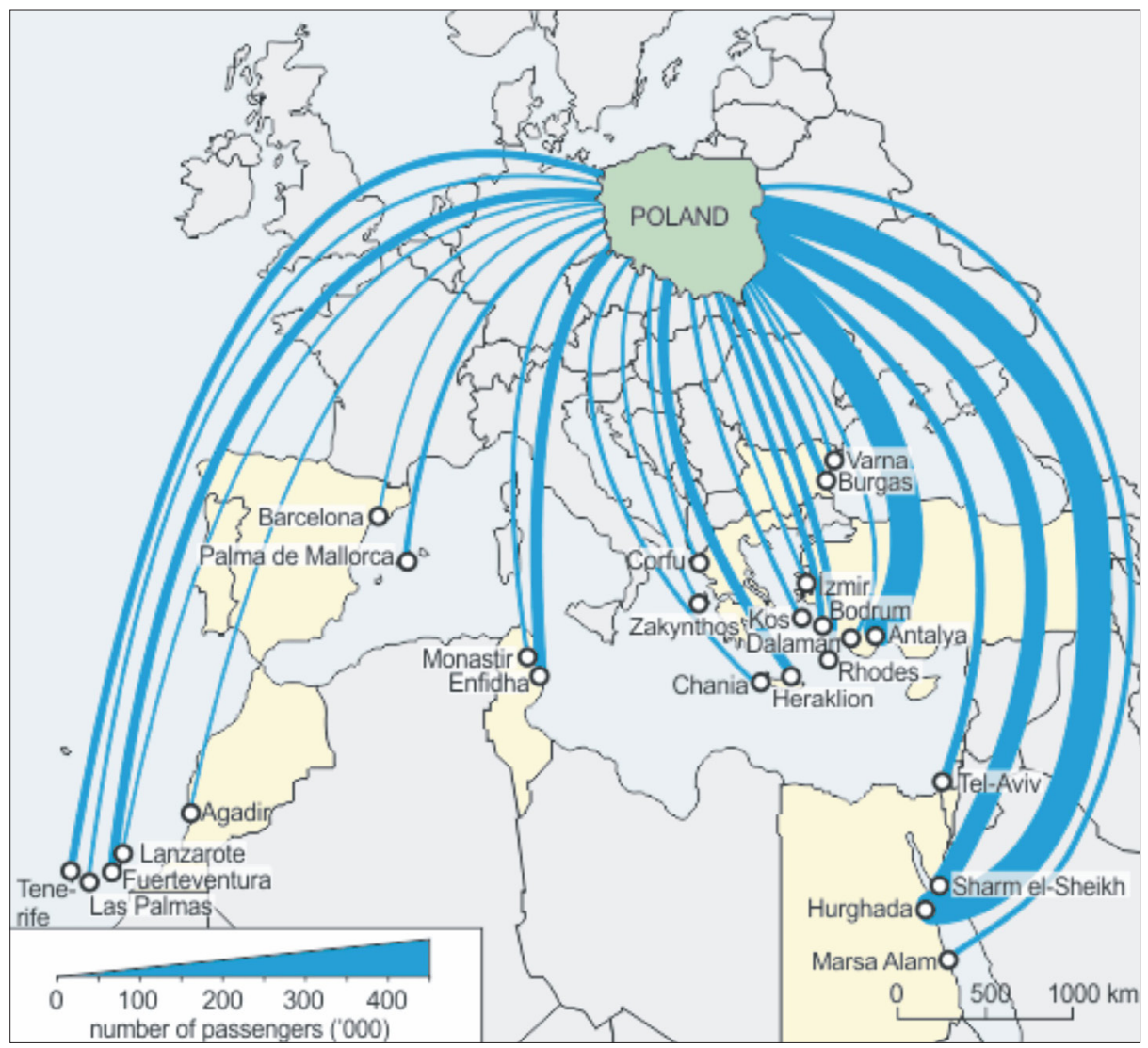

Fig. 1: Main destinations of charter flights from Poland by numbers of passengers carried Source: ULC (2014); author's elaboration

dominate, and in the west Palma de Mallorca and Barcelona. Finally, a last concentration embraces the Canary Islands and Moroccan Agadir. More important destinations on the Canary Islands are Fuerteventura and Tenerife, while more minor ones are Las Palmas and Lanzarote. By-and-large, the main directions taken by charter flights point explicitly to the domination of typical leisure trips (the so-called sun, sea and sand destinations) where mass organised tourist traffic is concerned.

The report Loty czarterowe z Polski - lato 2012 - as mentioned above - makes possible a closer look at charter flight departures from individual Polish airports. And although ten airports offering charter flights in the summer of 2012 are included, differences in the methodology of data collection unfortunately denote a lack of full comparability of the information. For this reason, a more detailed characterisation will confine itself to charter flights from central Warsaw's Chopin Airport, as well as the regional Bydgoszcz Airport. The eight other airports included in the report provided information on tour operators, some even on frequencies of flights, but not on carriers serving individual connections.

Warsaw Chopin Airport has at its disposal the fullest offering of charter flights of any Polish airport. In 2012, 1.4 million passengers used charter flights from Warsaw Airport. This is despite the fact that charter passengers represent a small minority of all the (9.6 million) travellers served at that airport. They were able to choose from among 49 different charter connections in the summer of that year (Fig. 2). A dozen or so carriers provided charter flights on behalf of the majority of the Polish tour operators. The most common destinations were Egyptian Hurghada and Turkish Antalya, as served by seven carriers each, and then Egyptian Sharm
el-Sheikh, served by six operators. Five charter carriers provided services to Cretan Heraklion (Iraklion) and Bulgarian Burgas and Varna. Other destinations were served by smaller numbers of carriers.

What are the origins of the carriers serving charter connections from Warsaw (Fig. 3)? The majority of the airlines in fact come either from Poland (Enter Air, LOT Polish Airlines, OLT Express Poland, Travel Service Polska, Bingo Airways and SprintAir), or from the neighbouring Czech Republic (Travel Service) and Lithuania (Small Planet Airlines). Then there are the cases of Bulgaria (only in the case of Varna does Bulgarian Air Charter also fly), Croatia, Cyprus, Egypt (Air Cairo and Nesma Airlines also fly to Hurghada and Sharm el-Sheikh), Georgia, Greece, Israel, Italy, Morocco, Portugal and Spain. Only the links with Malta and Ukraine are served by airlines from the destination countries (Air Malta and Air Onix, respectively). In the case of Turkey, besides the Polish and Lithuanian carriers, there are also three Turkish operators providing connections (Pegasus Airlines, Sky Airlines, Corendon Airlines), while the two Polish lines flying to Tunisia are joined by the Tunisian Nouvelair and Syphax Airlines.

Bydgoszcz Airport is one of the smallest regional airports in Poland, serving a total of just 358,052 passengers (2012). This airport offers its travellers few scheduled connections, in that the only carrier providing regular foreign flights is the Irish low-cost Ryanair. The network of connections is enriched by charter flights, of which there were ten in the summer season in 2012, made use of by 32,186 passengers in total. Thanks to the charter connections, the inhabitants of the city of Bydgoszcz and the hinterland area can travel to the Canary Islands, Greece, Croatia, Bulgaria, Tunisia, Turkey and Egypt (Fig. 4). 


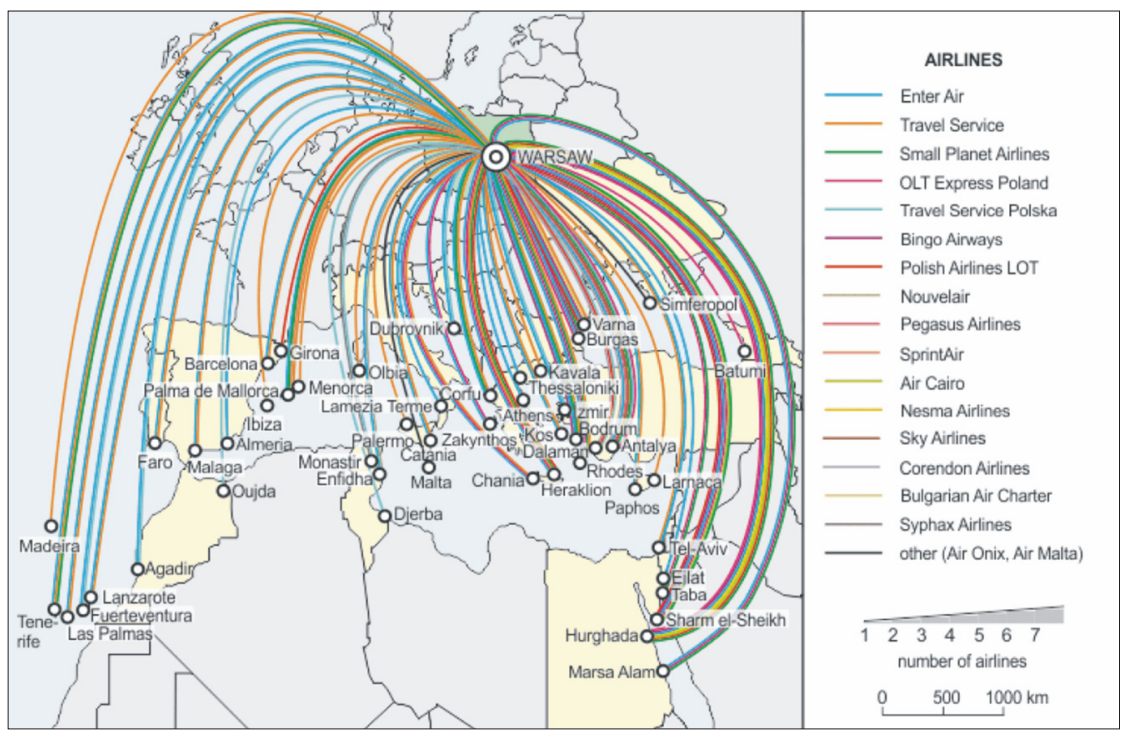

Fig. 2: Main destinations of charter flights from Warsaw by numbers of carriers serving the connection Source: Tanie loty (2012); author's elaboration

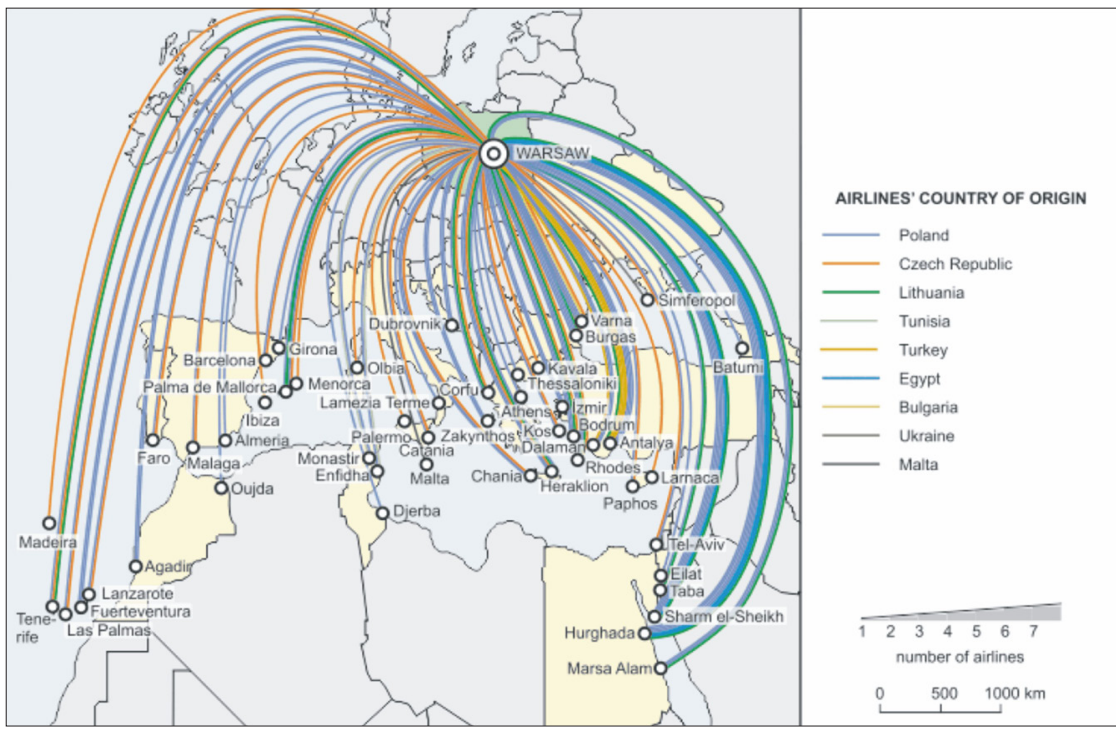

Fig. 3: Main destinations of charter flights from Warsaw by numbers of carriers serving the connection and country of registration. Source: Tanie loty (2012); author's elaboration

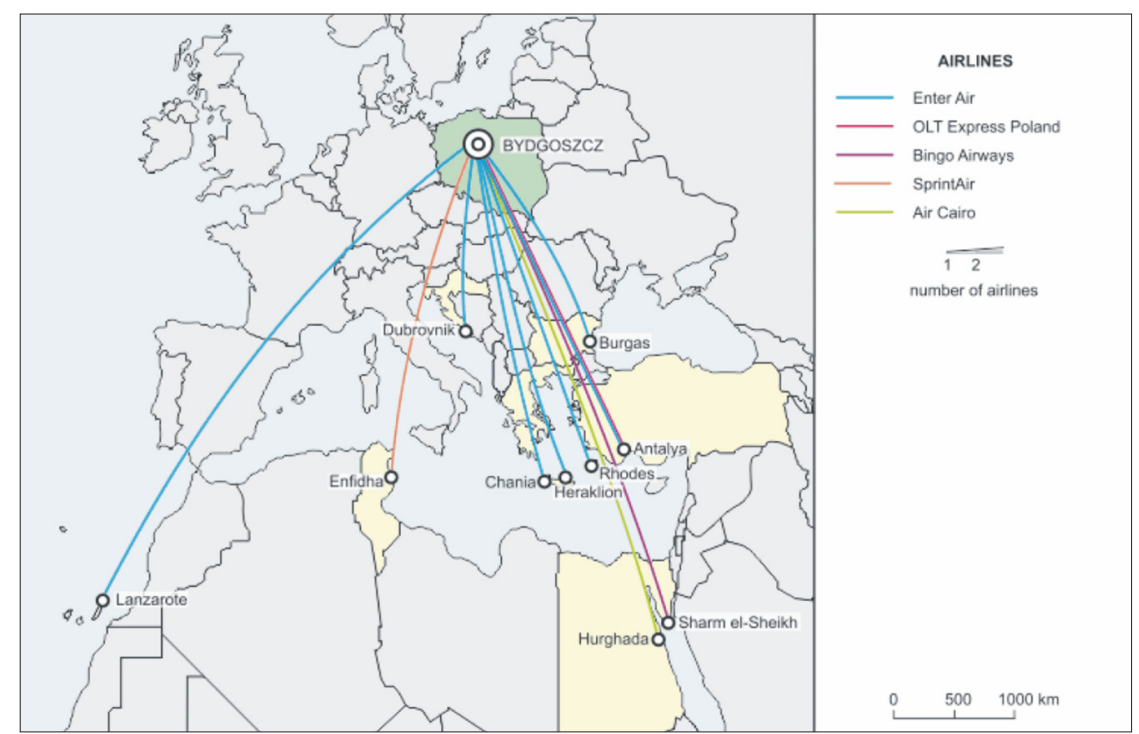

Fig. 4. Main destinations of charter flights from Bydgoszcz by numbers of carriers serving the connection Source: Tanie loty (2012); author's elaboration 
In summer, excursions from Bydgoszcz are offered by TUI Poland, Rainbow Tours, Itaka, Oasis Tours, Grecos Holiday, GTI Travel Poland, Exim Tours, Alfa Star, Neckermann Polska, Wezyr Holidays and 7islands, as well as by Triada and Sky Club, which have since closed down (in 2012). Tour operators use the services of five carriers providing charter flights, i.e. Air Cairo, Enter Air, Bingo Airways, SprintAir and OLT Express Poland. With the exception of the Egyptian Air Cairo, all of these are Polish carriers.

\section{Discussion}

In 2009, Dobruszkes wrote: "the market between Central Europe and the tourist destinations of southern Europe has not been sufficiently developed to date to give rise to any significant competition" (Dobruszkes, 2009a, p. 35). Moreover, the direction of the bulk of flights (north to south, and back) explains the relatively limited involvement of the low-costs in the servicing of organised tourist traffic. As is known from elsewhere, the majority of low-cost connections with Poland take a completely different course, namely in the east-west direction (Dobruszkes, 2009b; PijetMigoń, 2012), and therefore cannot serve mass organised tourist traffic very readily. In this case, low-cost carriers serve quite different segments of the market, namely gainful employment, visiting friends and relatives, and individual tourism - first and foremost. Thus, localities in the UK, Ireland, Norway or Germany, for example, are much more common destinations among passengers of LCCs. In this respect a great difference between West European and Polish markets emerges when comparisons are made, although the situation may change sooner or later.

Information on the tour operators and their various carriers confirms the extreme price-sensitivity of the Polish tourist market, and thus accounts for the great popularity of the cheapest carriers coming in to the market and seeking to draw immediate attention with their lower fares. As Martín et al. (2008, p. 214) write, "many leisure travellers are likely to choose the lowest-priced carrier, regardless of service quality". As already mentioned, among aircraft services, the cheapest are charter flights, hence their extreme popularity with Polish customers. And this is a substantial difference when compared with the more affluent societies of Western and Northern Europe in which low-cost carriers play a much greater role in carriage to leisure centres in the Mediterranean area as conceived broadly. There are certain common operational and economic features, but also obvious advantages of LCCs when compared with traditional charters, i.e. greater flexibility of departure days and times, and hence a move away from the one- or two-week travel and packages offered by tour operators (Doganis, 2006, p. 186), though these of course come at a price.

As has been noted, the situation may change in the future, with the growing affluence of Polish society. As Graham (2006, p. 20) says: "In the less-developed economies, it is likely that economic growth will still play a significant role in stimulating travel growth of new travellers beyond the level of GDP growth". One should also remember here that rather a large number of Poles spend their vacation in their own country, but may one day become customers of charter flights, first and foremost. A comparison of numbers of passengers on charter flights in Poland and in Western European countries indicates that the former market remains very far from saturation at this stage. For example, in the UK in the early 2000 s, charters alone carried over 30 million travellers, i.e. 29 per cent of passengers carried by all UK airlines (...) between European countries (Buck and Lei, 2004, p. 72). This reflects the fact that the Polish market for international leisure travel by air is relatively underdeveloped, while its British counterpart is fully mature.

Thus, although "most European countries have experienced a decline in passenger demand for charter flights" and "further decline is inevitable, as LCCs expand their networks across Europe and further afield" (Williams, 2008, p. 101) - this need not be the case for Poland. Yet in 2007, the number of charter links from/to Poland did not meet the demand for carriage exerted by tour operators (Gardzińska and Meyer, 2008, p. 138). Therefore, the possible decline could potentially be connected with, among other things, the natural choice of a younger and better-educated generation of consumers (whose tastes and expectations change) and the growing affluence of Polish society. Williams foresees a replacement of package tour charter flights by LCCs on most short-haul markets (Williams, 2008, p. 101), but this has a price which will not necessarily be appreciated by potential customers. To complicate the situation even more, a majority of charter airlines used by Polish tour operators (with the above mentioned exception of TUI Poland and Neckermann Polska) are not vertically integrated with each other in the manner seen to be very common in Western Europe.

Moreover, charter carriers and tour operators are now moving towards 'dynamic packaging', offering customers "a much higher level of flexibility, both in relation to the flight, and also in terms of holiday accommodation and duration of stay" (Doganis, 2006, p. 187). In future, Doganis sees charters as generating "most of their business from the denser, short-haul, inclusive-tour markets and from longhaul routes" (Doganis, 2006, p. 195), but smaller charter airlines may find it difficult to survive in the longer term. Therefore, there is a future for series charters, if perhaps a more limited one. The most probable future scenario sees simultaneous parallel coexistence of charter airlines and LCCs, albeit with respective shares in passenger traffic that remain difficult to foresee.

\section{Conclusions}

These days the aeroplane plays the decisive role in the servicing of mass organised tourist traffic. This statement is above all true when related to foreign outward tourism, and charter flights which prevail among instances of travel organised by Polish tour operators.

The number of registered charter carriers used by tour operators with headquarters in Poland alone is 126 , but collaboration with a large number has been on an occasional basis at best. It is apparently usual for carrier companies to hail from Central Europe or the Mediterranean basin area. Information on cooperation between individual tour operators and charter air carriers can be confirmed.

Home carriers besides LOT Polish Airlines, in practice limit their activities to charter flights. The largest of these is Enter Air, with its fleet of 12 passenger aircraft. The remaining companies play a much more limited role, with fleets not exceeding 5 aeroplanes each (Bingo Airways and SprintAir, not to mention YES Airways incorporated by OLT Express Poland, which together with OLT Express Regional ceased trading in mid-2012). One company is an affiliate of the Czech-scheduled and charter Travel Service a.s. operator (Travel Service Polska). The presence of separate viable, or even vibrant air charter companies that are not part of large tour operators seems to be something of a regional speciality. 
Polish air carriers other than LOT Polish Airlines are exclusively privately-owned. LOT is a company with a long tradition (founded 1929), but the majority of Poland's private charter carriers have only recently entered the market. Moreover, the segment of charter carriers has thus far been seen to be under continuous transformation.

Large tour operators of foreign origin (e.g. Neckermann Polska of the Thomas Cook Group, TUI Poland - an affiliate of TUI Travel plc) have their own airlines (Thomas Cook Airlines, Condor Airlines, etc.). The vertical integration is to lower transaction costs and uncertainty, while simultaneously synchronising supply and demand along the entire supply chain of products. It therefore helps with the achievement of their own objectives, but also makes surpluses available to competing tour operators. Sometimes tour operators own not only an air carrier, but also shares in other transport companies (capital links between TUI and Air Berlin, for example). Therefore, the situations of 'native' and 'foreign' origin tour operators seem to differ.

In the Polish market we also observe airlines belonging to tour operators that are not directly engaged more widely in other activity (e.g. Globalia Tourism, Gropo Iberostar and Balkan Holiday).

The Polish tour operators requiring charter flights mainly utilise domestic carriers, as well as one or two significant ones from neighbouring countries (the Czech Republic and Lithuania). Moreover, it is quite common for use to be made of air carriers in reception countries (Turkey, Tunisia, Egypt, Israel, Greece and Bulgaria). Beyond Europe and the Mediterranean basin, the only significant charter carrier is the low-cost Air Arabia, with headquarters in the United Arab Emirates.

There are also charter flights of the LCCs (Turkish Corendon Airlines and Onur Air, and the already-mentioned Air Arabia), but this is not a frequent phenomenon. At least some scheduled low-costs take part on a limited scale in the servicing of organised tourist traffic (e.g. Wizz Air, easyJet and Norwegian Air Shuttle), which reflects their above-mentioned servicing of other segments of the market. Taking into account the greater flexibility of the LCCs, however, this situation may change in the future.

\section{Acknowledgment}

This research was funded by a National Centre for Science (NCN) project under 2011/01/B/HS4/00837.

\section{References:}

BARRETT, S. (2008): The emergence of the low cost carrier sector. In: Graham, A. et al. [eds.]: Aviation and Tourism. Implications for Leisure Travel (pp.103-118). AldershotBurlington, VT, Ashgate.

BIEGER, T., WITTMER, A. (2006): Air transport and tourism - Perspectives and challenges for destinations, airlines and governments. Journal of Air Transport Management, 12(1): 40-46.

BUCK, S., LEI, Z. (2004): Charter airlines: Have they a future? Tourism and Hospitality Research, 5(1): 72-78.

Central Register of Tourist Agencies and Tourist Brokers (CEOTiPT) (2014): Centralna ewidencja organizatorów turystyki i pośredników turystycznych [online]. [cit. 07.03.2014]. Available at www.turystyka.gov.pl/ceotipt/ statystyki/statystyka/2/
DOBRUSZKES, F. (2006). An analysis of European lowcost airlines and their networks. Journal of Transport Geography, 14(4): 249-264.

DOBRUSZKES, F. (2009a): Does liberalisation of air transport imply increasing competition? Lessons from the European case. Transport Policy, 16(1): 29-39.

DOBRUSZKES, F. (2009b): New Europe, new low-cost air services. Journal of Transport Geography, 17(6): 423-432.

DOBRUSZKES, F. (2013): The geography of European lowcost airline networks: A contemporary analysis. Journal of Transport Geography, 28: 75-88.

DOBRUSZKES, F. (2014): Geographies of European air transport. In: Goetz, A. R., Budd, L. [eds.]: The Geographies of Air Transport (pp. 167-186). AldershotBurlington, VT, Ashgate.

DOBRUSZKES, F., MONDOU, V. (2013): Aviation liberalization as a means to promote international tourism: The EU-Morocco case. Journal of Air Transport Management, 29: 23-34.

DOGANIS, R. (2006): The Airline Busines. London-New York, Routledge, $2^{\text {nd }}$ edition.

DOGANIS, R. (2010): Flying Off Course. Airline Economics and Marketing. London-New York, Routledge, $4^{\text {th }}$ edition.

FRANCIS, G., HUMPREYS, I., ISON, S., AICKEN, M. (2006): Where next for low cost airlines? A spatial and temporal comparative study. Journal of Transport Geography, 14(2): 83-94.

GARDZIŃSKA, A., MEYER, B. (2008): Znaczenie lotów czarterowych i niskokosztowych w obsłudze ruchu turystycznego w Polsce. In: Panasiuk, A., Pluciński, M. [eds.]: Transport lotniczy i morski w obsłudze ruchu pasażerskiego. Implikacje dla regionów (pp. 135-143). Szczecin, Uniwersytet Szczeciński, Zeszyty Naukowe, 491.

GRAHAM, A. (2006): Have the major forces driving leisure airline traffic changed? Journal of Air Transport Management, 12(1): 14-20.

GRAHAM, A., PAPATHEODOROU, A., FORSYTH, P. [eds.] (2008): Aviation and Tourism. Implications for Leisure Travel. Aldershot-Burlington, VT, Ashgate.

GRAHAM，B. (1998): Liberalization, regional economic development and the geography of demand for air transport in the European Union. Journal of Transport Geography, 6(2): 87-104.

GRAHAM, B. (2008): New air services: Tourism and economic development. In: Graham, A. et al. [eds.]: Aviation and Tourism. Implications for Leisure Travel (pp. 227-237). Aldershot-Burlington, VT, Ashgate.

GRAHAM, B., SHAW, J. (2008): Low-cost airlines in Europe: Reconciling liberalization and sustainability. Geoforum, 39(3): 1439-1451.

HALL, D. R. (1999): Conceptualising tourism transport: Inequality and externality issues. Journal of Transport Geography, 7(3): 181-188.

HALL，D. (2008): Transport, tourism and leisure. In: Knowles, R. et al. [eds.]: Transport Geographies. Mobilities, Flows and Spaces (pp. 196-211). MaldenOxford-Carlton, Blackwell.

HALSALL， D. (1992): Transport for tourism and recreation. In: Hoyle, B. S., Knowles, R. D. [eds.]: 
Modern Transport Geography (pp. 155-177). LondonNew York, Belhaven Press.

InfoVeriti (2013): The Info Veriti Polska service making available reports of companies submitted to Krajowy Rejestr Sądowy [online]. [cit. 05.10.2013]. Available at http://krs.infoveriti.pl/

IOANNIDES, D. (1998): Tour operators: The gatekeepers of tourism. In: Ioannides, D., Debbage, K. G. [eds.]: The Economic Geography of the Tourist Industry. A Supplyside Analysis (pp. 139-158). London-New York, Routledge.

JANKIEWICZ, J., HUDEREK-GLAPSKA, S. (2016): The air transport market in Central and Eastern Europe after a decade of liberalisation - Different paths of growth. Journal of Transport Geography, 50: 45-56.

MARTÍN, J. C., ROMÁN, C., ESPINO, R. (2008): Willingness to pay for airline service quality. Transport Reviews, 28(2): 199-217.

PEETERS, P., SZIMBA, E., DUIJNISVELD, M. (2007): Major environmental impacts of European tourism transport. Journal of Transport Geography, 15(2): 83-93.

PIJET-MIGOŃ, E. (2012): Zmiany rynku lotniczych przewozów pasażerskich w Polsce po akcesji do Unii Europejskiej. Wrocław, Uniwersytet Wrocławski, Rozprawy Naukowe Instytutu Geografii i Rozwoju Regionalnego, 25.

PRIDEAUX, B. (2000): The role of transport system in destination development. Tourism Management, 21(1): 53-63.
Tanie loty (2012): Loty czarterowe z Polski - lato 2012 [online]. [cit. 04.02.2014]. Available at https://www.tanieloty.com.pl/blogi/1848-raport-loty-czarterowe-z-polskilato-2012.html

ULC (Civil Aviation Authority) (2014): Statystyki i analizy rynku transportu lotniczego [online]. [cit. 10.02.2014]. Available at www.ulc.gov.pl/pl/regulacja-rynku/324statystyki-i-analizy

WiadomościTurystyczne(2012):Touroperatorzy Raport2012. Wydanie specjalne 16.06.2012 [online]. [cit. 04.08.2016]. Available at http://www.wiadomosciturystyczne.pl/files/ Touroperatorzy\%20RAPORT\%202012.pdf

Wiadomości Turystyczne (2013): Touroperatorzy Raport 2013. Wiadomości Turystyczne. Wydanie specjalne 16.06.2013 [online]. [cit. 04.08.2016]. Available at http://www.wiadomosciturystyczne.pl/pdf/2013/ touroperatorzy2013.pdf

WHEATCROFT, S. (1998): The airline industry and tourism. In: Ioannides, D., Debbage, K. G. [eds.]: The Economic Geography of the Tourist Industry. A Supply-side Analysis (pp. 159-179). London-New York, Routledge.

WILLIAMS, G. (2001): Will Europe's charter carriers be replaced by "no-frills" scheduled airlines? Journal of Air Transport Management, 7: 277-286.

WILLIAMS, G. (2008): The future of charter operations. In: Graham, A. et al. [eds.], Aviation and Tourism. Implications for Leisure Travel (pp. 85-102). AldershotBurlington, VT, Ashgate.

\section{Please cite this article as:}

TAYLOR, Z. (2016): Air charter leisure traffic and organised tourism in Poland: Are charters passé? Moravian Geographical Reports, 24(4): 15-25. Doi: 10.1515/mgr-2016-0019. 